\title{
TOTAL LIPID AND FATTY ACID ACCUMULATION DURING BASIDIOSPORE FORMATION IN THE ECTOMYCORRHIZAL FUNGUS Pisolithus SP.(1)
}

\author{
André Narvaes da Rocha Campos ${ }^{(2)}$, Maurício Dutra Costa ${ }^{(3,4)}$, \\ Marcos Rogério Tótola ${ }^{(4)} \&$ Arnaldo Chaer Borges ${ }^{(4)}$
}

\begin{abstract}
SUMMARY
The basidiospores of Pisolithus sp. contain large amounts of lipids, indicating provision for future germination in the host rhizosphere. However, the accumulation, composition, and mobilization of lipids during formation and germination of these spores are largely unknown. In this study, lipid storage and fatty acid composition during basidiosporogenesis were analyzed in fresh basidiocarps using bright-field microscopy and gas chromatography. Abundant lipid bodies are found in the hyphae, basidia, and basidiospores of fungal basidiocarps. This evidences a considerable $\mathrm{C}$ transport in the basidiocarp to meet the $\mathrm{C}$ demand during basidiospore formation. Fatty acid composition analysis revealed the presence of 24 compounds with chains of 9 to $18 \mathrm{C}$ atoms, either saturated or insaturated, with one or two insaturations. The fatty acid composition and content varied according to the developmental stage of the peridioles. In free basidiospores, the predominant compounds were 16:0, 16:1w5c, 18:1w9c, and 18:2w6,9c/18:0ante, at concentrations of $76,46,192$, and $51 \mu \mathrm{g} \mathrm{g}^{-1}$ dry matter, respectively. Our results indicate that oleic acid is the major constituent of lipid reserves in Pisolithus sp. basidiospores. Further studies are being conducted to determine the factors that induce lipid mobilization during spore germination.
\end{abstract}

Index terms: Basidiomycota, basidiosporogenesis, carbon storage, ectomycorrhiza, fatty acids.

\footnotetext{
(1) Parte da Dissertação de Mestrado do primeiro autor no Programa de Pós-graduação em Microbiologia Agrícola da Universidade Federal de Viçosa - UFV. Apoio financeiro Capes e FAPEMIG projeto CAG 775/03. Recebido para publicação em agosto de 2006 e aprovado em abril de 2008.

(2) Doutorando do Programa de Programa de Pós-graduação em Microbiologia Agrícola, Departamento de Microbiologia, Universidade Federal de Viçosa - UFV. CEP 36570-000 Viçosa (MG). Bolsista CAPES. E-mail: rochacampos@yahoo.com.br

(3) Professor Orientador do Programa de Pós-graduação do Departamento de Microbiologia, UFV. E-mail: mdcosta@ufv.br

(4) Professor Adjunto do Departamento de Microbiologia, UFV.
} 


\title{
RESUMO: $\quad$ ACÚMULO DE LIPÍDEOS TOTAIS E DE ÁCIDOS GRAXOS DURANTE A FORMAÇÃO DE BASIDIÓSPOROS NO FUNGO ECTOMICORRÍZICOPisolithus SP.
}

\begin{abstract}
Os basidiósporos de Pisolithus sp. contêm grande quantidade de lipídeos, indicando provisão para futura germinação na rizosfera da planta hospedeira. No entanto, pouco se conhece a respeito do acúmulo, da composição e da mobilização dos lipídeos durante a formação e germinação dos esporos. Neste trabalho, o armazenamento de lipídeos e a análise da composição em ácidos graxos durante a basidiosporogênese foram estudados utilizando-se técnicas de microscopia de luz e cromatografia gasosa. O basidiocarpo fúngico apresentou abundantes corpos lipídicos no interior de suas hifas, basídios e basidiósporos. Esse fato evidencia considerável transporte de $C$ dentro do basidiocarpo para suprir a demanda de $C$ durante a formação dos esporos. A composição de ácidos graxos revelou a presença de 24 compostos com cadeias variando de 9 a 18 átomos de $C$, sendo tanto saturados ou contendo uma ou duas insaturações. A composição de ácidos graxos variou de acordo com o estádio de desenvolvimento dos peridíolos. Nos basidiósporos livres, os compostos predominantes foram 16:0, 16:1 w5c, 18:1 w9c e 18:2w6,9c/18:0ante, com concentrações de 76, 46, 192 e $51 \mu \mathrm{g} \mathrm{g}^{-1}$ do ácido graxo de matéria seca, respectivamente. Esses resultados indicam que o ácido oléico é o principal constituinte das reservas lipídicas nos basidiósporos de Pisolithus sp. Outros trabalhos estão sendo realizados para determinar os fatores que desencadeiam a mobilização de lipídeos durante a germinação de esporos.
\end{abstract}

Termos de indexação: Basidiomycota, basidiosporogênese, reservas de carbono, ectomicorriza, ácidos graxos.

\section{INTRODUCTION}

The ectomycorrhizal fungus Pisolithus is a gasteromycete with wide geographical distribution, capable of associating with plants of economic interest such as Pinus and Eucalyptus (Chambers \& Cairney, 1999). The dispersion of this fungus in the natural environment is partly due to the large quantity of spores produced in the fungal basidiocarps (Brundrett et al., 1996). The subsequent basidiospore germination requires energy and precursor compounds for the production of a germination tube, initial hyphae growth and the establishment of ectomycorrhizal association.

Lipids are important storage compounds in filamentous fungi and have been reported in different fungal structures, such as sexual spores (Wells, 1965; Mims, 1980; Yoon \& McLaughlin, 1986; Feofilova et al., 2004), in conidia (Morozova et al., 2002) and in vegetative hyphae (Kamisaka et al., 1999; Laczko et al., 2003). Lipids also take part in the $\mathrm{C}$ metabolism of mycorrhizal associations. In arbuscular mycorrhizal fungi, these compounds are produced by the fungal partner in the host roots (Pfeffer et al., 1999) and are subsequently transferred to the extraradical hyphae and spores (Bago et al., 2002), metabolized by $\beta$-oxidation and the glyoxylate cycle enzymes (Lammers et al., 2001; Bago et al., 2002). The germination of spores of arbuscular mycorrhizal fungi involves both the lipid transport and subsequent metabolism in the newly formed germination tube and hyphae (Bago et al., 2002).
Likewise, lipid metabolism is important in ectomycorrhizal associations. The expression of malate synthase increases in the initial stages of the symbiosis between Laccaria bicolor and Pinus resinosa (Balasubramaniam et al., 2002). The possibility of plant-to-fungus transfer of lipids as $\mathrm{C}$ source has also been suggested in the association Pisolithus tinctorius - Pinus sylvestris (Laczko et al., 2003).

During the maturation of Pisolithus basidiospores, lipids are accumulated in the spores (Mims, 1980). Lipid reserves fill almost the whole space within mature basidiospores, pressing cell organelles, such as the nucleus, against the spore cell wall (Mims, 1980; Costa, 2002). It is hypothesized that the origin of these lipid reserves is the fibrillar matrix in the fungal peridioles, since no lipid bodies were observed in the basidia (Mims, 1980). Besides constituting the lipid reserves, fatty acids can have additional roles in fungi. They have been associated with the inhibition or stimulation of spore germination, cell lysis, and induction of the sexual stage (Jee \& Ko, 1997; Wang et al., 2002).

Despite the abundant lipid reserves in Pisolithus spp. basidiospores, spore germination percentages are extremely low, varying from 0.001 to $0.38 \%$ (Kope \& Fortin, 1990; Costa, 2002; Pereira, 2004). Information about the composition of the fatty acids that constitute the storage products may be useful for the elucidation of the factors that lead to spore germination in this important ectomycorrhizal genus. Therefore, the objective of this work was to characterize the 
accumulation of lipid reserves associated with the process of basidiospore formation in Pisolithus sp.

\section{MATERIAL AND METHODS}

This work was conducted at the Mycorrhizal Associations Laboratory, Microbiology Department, Universidade Federal de Viçosa (UFV), Viçosa, MG, Brazil. The biological material consisted of fresh basidiocarps of Pisolithus sp. from a Eucalyptus sp. forest of the Sylviculture Section, UFV, collected from August 2003 to December, 2004. Basidiocarp samples were air-dried and deposited in the Vic Herbarium (code VIC 26495).

\section{Distribution of total lipids in hyphae, basidia, and developing basidiospores}

For the characterization of the total lipid reserves, peridioles at different developmental stages were removed from a fresh basidiocarp, fixed in $10 \%$ formalin for four hours, mounted in Jung Tissue Freezing Medium ${ }^{\mathrm{TM}}$, and sectioned at $-20^{\circ} \mathrm{C}$ in a Leica CM 1850 cryomicrotome, producing $25 \mu \mathrm{m}$ sections. The sections were immersed in phosphate buffer, $\mathrm{pH}$ 7.0, and stained for 15 min in $2 \%$ Sudan Black B prepared in $70 \%$ ethanol (Behmer et al., 1976). After staining, the sections were washed thrice in phosphate buffer and stained with $1 \%$ Congo Red and gently transferred to microscope slides. The preparations were observed under a Nikon E600 light microscope, photographed with a Fujix HC-300Z digital camera, and the images processed with the programs Photograb and EZTouch (Fujifilm).

As a negative control for the staining procedure the sections were treated with methanol/chloroform/ water/hydrochloric acid (66:33:4:1) to remove lipids from hyphae, basidia, and basidiospores, followed by the staining procedure described above.

For the characterization of the lipid reserves in mature basidiospores, a suspension containing $1 \mathrm{~g}$ of free spores in $15 \mathrm{~mL} 0.05 \%$ Tween 80 was prepared. The suspension was centrifuged at $11.000 \mathrm{~g}$ for two minutes and the basidiospores suspended in distilled water. The washing procedure was repeated twice. Aliquots of $250 \mu \mathrm{L}$ of the suspension were transferred to $1.5 \mathrm{~mL}$ Eppendorff tubes and treated for $50 \mathrm{~s}$ with $250 \mu \mathrm{L}$ sodium hypochlorite containing $20 \mathrm{~g} \mathrm{~L}^{-1}$ active chloride. This treatment was interrupted by adding $500 \mu \mathrm{L}$ of $0.14 \mathrm{~mol} \mathrm{~L}^{-1}$ sodium thiosulfate. The suspensions were centrifuged at $11.000 \mathrm{~g}$ for two minutes and the basidiospores were resuspended in $200 \mu \mathrm{L}$ Sudan Black B prepared as described above. After 15 min of staining, the suspension was centrifuged as above and washed twice with distilled water to eliminate dye excess. The basidiospores were finally suspended in $125 \mu \mathrm{L}$ distilled water. Five microliters of this suspension were mixed with $5 \mu \mathrm{L}$ of $1 \%$ Congo Red and observed under a microscope as described above.

\section{Fatty acid composition analysis}

The fatty acid composition of three basidiocarps was determined at five different positions of the fungal fruit body: lower portion containing undifferentiated peridioles, middle portion containing newly differentiated young peridioles, upper portion containing fully developed peridioles, spores from the upper portion of a closed basidiocarp (enclosed basidiospores), and mature spores collected from the upper portion of a naturally ruptured basidiocarp (free basidiospores). Samples from the five regions were taken in triplicate for the determination of dry mass $\left(40{ }^{\circ} \mathrm{C}\right.$ to constant weight). Three other samples (40 mg fresh weight) were simultaneously taken for extraction and analysis of fatty acids. The samples were placed in Teflon-capped tubes following saponification of the fatty acids in $1 \mathrm{~mL}$ methanol/ sodium hydroxide (150 mL deionized water, $150 \mathrm{~mL}$ methanol, $45 \mathrm{~g}$ sodium hydroxide) at $100{ }^{\circ} \mathrm{C}$ for 30 min. Two milliliters of $6 \mathrm{~mol} \mathrm{~L}^{-1}$ methane in $\mathrm{HCl}$ were added to each tube and the mixture was incubated at $80^{\circ} \mathrm{C}$ for $10 \mathrm{~min}$. The separation of the fatty acid methyl esters from the acidic to the organic phase was carried out by adding $1.25 \mathrm{~mL}$ hexane:tertbutyl ether (1:1). After shaking for $10 \mathrm{~min}$, the lower phase was discarded and the upper phase containing the fatty acid methyl esters was recovered, washed with $0.25 \mathrm{~mol} \mathrm{~L}^{-1} \mathrm{NaOH}$, and stored at $20{ }^{\circ} \mathrm{C}$ until analysis. The fatty acid methyl esters were determined by gas chromatography using a HP 5890 Series II chromatograph. The fatty acids were identified and quantified using the Sherlock System (Microbial Identification System) by comparison with a TSBA Library 4.0. The data were used to calculate the mean and standard deviation for each developmental stage, considering each basidiocarp as a replication.

\section{RESULTS AND DISCUSSION}

\section{Distribution of total lipids during basidios- porogenesis}

The staining of hyphae, basidia, and spores with Sudan Black B evidenced the presence of lipids as black bodies conspicuously present during the whole process of basidiospore formation (Figure 1). Lipid inclusions were found in the hyphae, basidia, and basidiospores at each developmental stage (Figure 1). In the control treatment, lipids could not be detected in the fungal structures.

Lipid inclusions could be observed in the basidia and basidiospores as early as during basidiospore primordia production until the development of spines 
on the basidiospore surface at later basidiosporogenesis stages. Lipid inclusions may be responsible for the supply of $\mathrm{C}$ and energy for the synthesis of the spore cell wall, organelles and other important cell components (Figure 1a,b,c,d,e,f). The accumulation of remarkable quantities of lipids was only observed in basidiospores ornamented with the typical surface spines (Figure 1g,h).

The observation of storage lipids with Sudan Black in mature basidiospores was only possible after the chemical scarification of the spore wall with sodium hypochlorite. At this developmental stage, lipid compounds occupy almost the whole space within basidiospores (Figure 1h) and compress organelles against the spore cell wall, making the observation of cell constituents rather difficult (Mims, 1980; Costa 2002). At this stage, when nuclei are stained with SYBR Green $I^{\mathrm{TM}}$ they acquire a crescent shape and are always located at the cell periphery, near the spore wall (Costa, 2002).

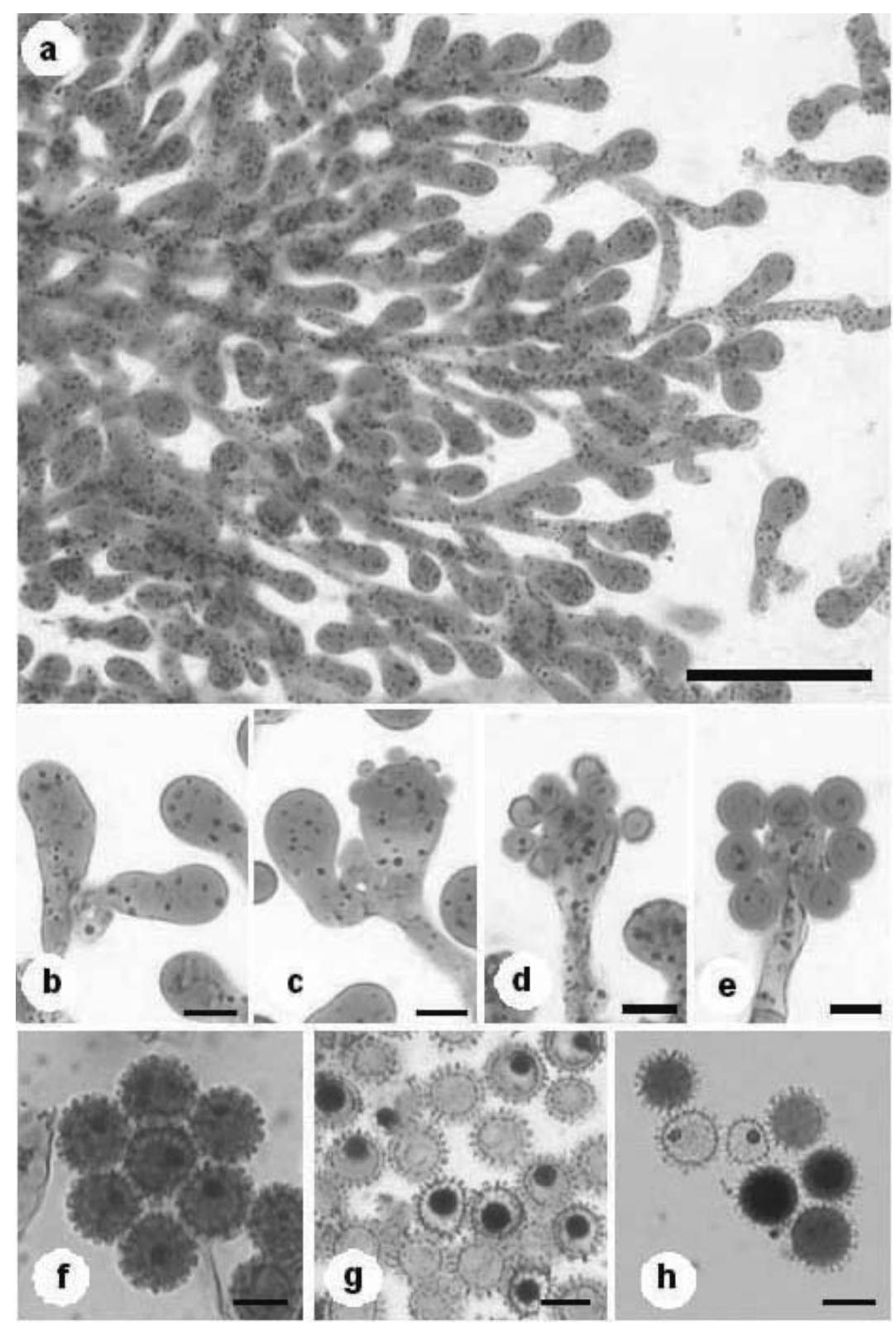

Figure 1. Hyphae, basidia, and basidiospores of Pisolithus sp., stained with Congo Red and Sudan Black B, showing the lipid distribution (black inclusions) in the fungal structures. (a) Abundant lipid distribution in young basidia and hyphae. (b) Lipids in a connection clamp located at the base of basidia. (b to g) Progress of lipid accumulation during basidiospore development. (h) Storage lipids in mature basidiospores taking the whole internal space of the spore (light brown to black spores). Bars: $\mathrm{a}=30 \mu \mathrm{m}$; $\mathrm{b}$ to $\mathrm{h}=5 \mu \mathrm{m}$. 
Lipid inclusions can be observed within basidia as well as in connection clamps (Figure 1b), raising questions as to the direction of the flux of these elements through the basidiocarp hyphae and the involvement of the cytoskeleton in this transport, as hypothesized for arbuscular mycorrhizal fungi (Bago et al., 2002).

The lipids deposited inside the basidiospores are probably derived from hyphae and basidia since a large quantity of lipid inclusions were observed within these structures at all developmental stages analyzed (Figure 1). The hypothesis of Mims (1980) that lipid reserves are constituted by lipid uptake by the spores from the gelatinous matrix within the peridioles cannot be discarded since uptake kinetics at this stage has not been investigated. However, the data presented herein strongly suggest that lipids may have to be taken up first by hyphal and basidial cells before reaching the basidiospores.

The presence of lipid inclusions in all regions of the basidiocarp are possibly due to the continuous transport of lipids from the extraradical mycelia to the fruit body. So far, the origin of the lipids in Pisolithus sp. basidiocarps is not known. Fatty acid synthesis may take place in situ or at other sites such as in extraradical hyphae (Pffefer et al., 1999) or in the ectomycorrhiza itself (Laczko et al., 2003). The increase in lipid synthesis in the roots of the host plant in response to mycorrhizal colonization is observed in $P$. sylvestris associated with $P$. tinctorius (Laczko et al., 2003). Lipid transfer from roots to hyphae was confirmed by a decrease in the content of root fatty acids and the simultaneous increase in the content of these compounds in the extraradical hyphae (Laczko et al., 2003).

For arbuscular mycorrhizal fungi, the role of lipids in fungal growth and dispersion is better known. Fatty acids are used in long-distance $\mathrm{C}$ transport, including during the storage of $\mathrm{C}$ in spores (Bago et al., 2002). The $\mathrm{C}$ taken up by mycorrhizas is used to synthesize lipids that are then transferred to extraradical hyphae (Pffefer et al., 1999). The presence of glyoxysome-like structures and the expression of malate synthase and isocitrate lyase in the hyphae of Glomus intraradices evidence the capacity of arbuscular mycorrhizal fungi to use fatty acids as C sources (Lammers et al., 2001).

Likewise, in the ectomycorrhizal fungus L. bicolor, the increase in the activity of malate synthase during pre-infection stages suggests that the cycle plays a role in enabling the fungus to use fatty acid metabolism derivatives and the regulation of the glyoxylate pathway by symbiosis (Balasubramaniam et al., 2002). For Pisolithus, the presence and function of the glyoxylate cycle remains unknown despite some studies that report the importance of lipid compounds for the fungal life cycle (Mims, 1980; Laczko et al., 2003).

\section{Fatty acid distribution during basidiospore formation}

Fatty acid composition analyses of Pisolithus sp. basidiocarps revealed the presence of 24 compounds distributed along the regions of the basidiocarp characterized by the different developmental stages (Figure 2). The fatty acids detected were either saturated or not (one or two insaturations), with chains containing 9-18 C atoms. Hydroxylated and methylated fatty acids were also detected (Figure 2; Table 1).

The distribution of fatty acids in the basidiocarps varied according to the developmental stages of the peridioles (Figure 2). Some fatty acids were shown to be specific of certain stages, while others were present in two or more stages. The variety of unique compounds in the undifferentiated peridiole region was larger (10:0 iso, 10:0 OH, 11:0 anteiso, 12:0, 12:0 3OH, 13:0, 13:0 anteiso, 14:0, 15:1 iso $\mathrm{F}, 15: 1 \mathrm{I} / \mathrm{H} / 13: 03 \mathrm{OH}$, 15:0 anteiso, and,17:1w9c). The young peridioles presented two distinct compounds $(9: 03 \mathrm{OH}$ and 12:0 ALDE), while in mature peridioles only one fatty acid characteristic of this stage was found (17:1 iso/ ante B).

The fatty acid 14:0 was detected in free basidiospores only. The fatty acids 15:0 and 17:1w8c were detected in the first three stages of basidiocarp development, while the fatty acid 18:0 was detected only in the last. The fatty acids 16:0, 16:1w5c, the mixture $16: 1 \mathrm{w} 7 \mathrm{c} / 15: 0 \mathrm{iso} 2 \mathrm{OH}, 18: 1 \mathrm{w} 9 \mathrm{c}$, and the mixture 18:2w6,9c/18:0ante were detected in all development stages (Figure 2). The modification of the fatty acid profile during peridiole development in Pisolithus sp. may be a result of alterations in the physiological and morphogenetic properties related to basidiospore development. Such changes during basidiosporogenesis were also reported in Agaricus bisporus (Feofilova et al., 2003).

The relative percentages of fatty acids varied from $<0.55$ to $71.25 \%$ and the concentration from $<6.00$ to $502.11 \mu \mathrm{g} \mathrm{g}^{-1}$ and from $<1.7$ to $217.7 \mu \mathrm{g} \mathrm{g}^{-1}$, based on dry and fresh matter, respectively (Table 1). A higher variation in the concentration of fatty acids with shorter $\mathrm{C}$ chains indicated that alternative methodologies should be used to quantify this fraction of the fruit body lipids.

Despite the highest diversity of fatty acids in the undifferentiated peridiole region, most of these compounds were detected in low quantities. In this portion of the basidiocarp, the fatty acid profile observed was similar to the pattern reported for the mycelium of Pisolithus tinctorius (Lackzo et al., 2003), suggesting morphological and biochemical similarity of this region with the vegetative hyphae.

The presence of unique fatty acids at distinct developmental stages of the basidiocarps of Pisolithus 


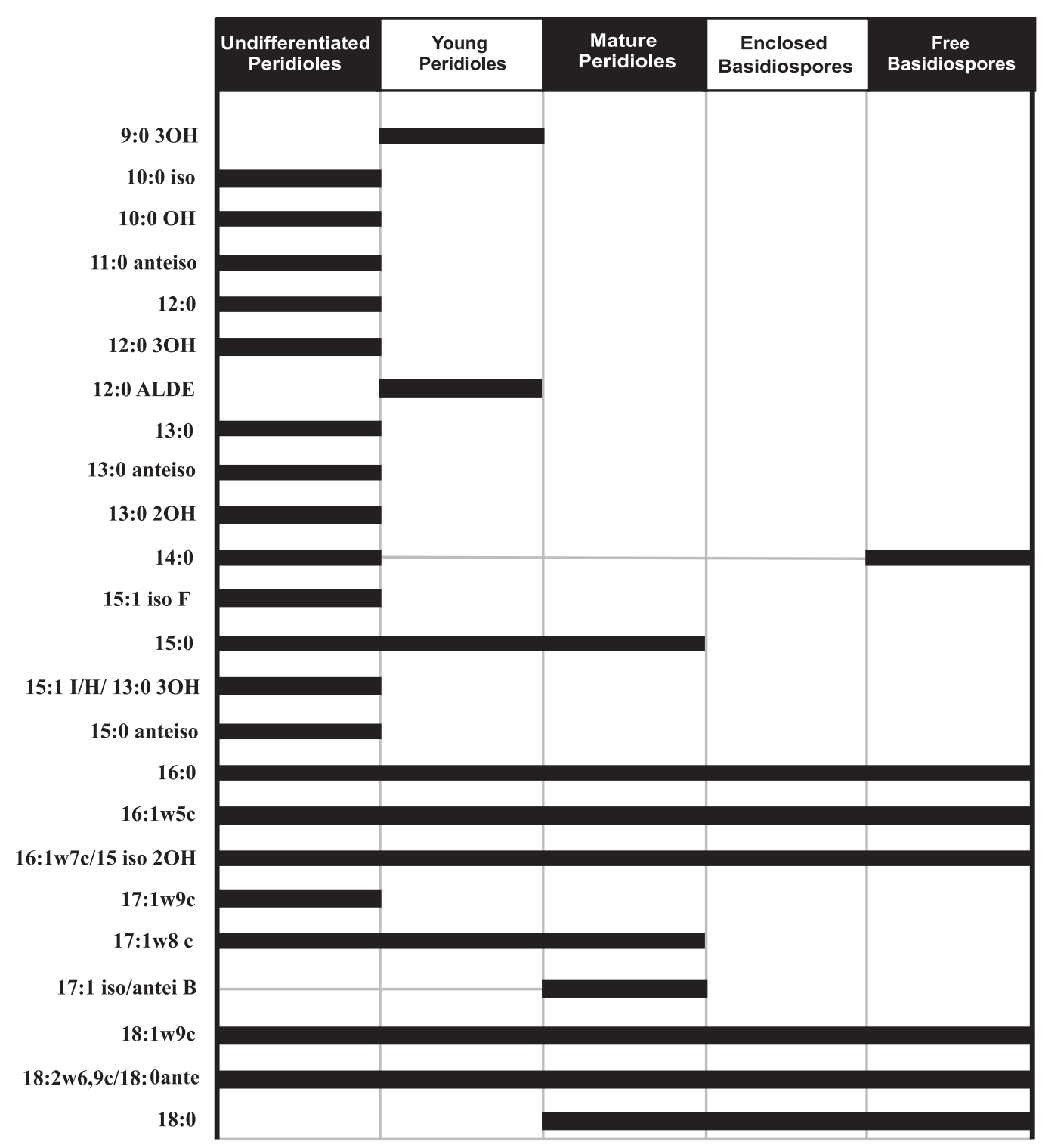

Figure 2. Distribution of fatty acids during the development of the peridioles that constitute the basidiocarps of Pisolithus sp.

sp. may be related to the processes of cell differentiation towards basidiospore production. To corroborate this hypothesis, it was observed that sexual reproduction can be stimulated in Phytophthora cactorum and Phytophthora parasitica by free fatty acids in the culture medium (Jee \& Ko, 1997). The main inducer fatty acid reported in this study was palmitic acid.

The fatty acids 16:0, 16:w5c, 18:1w9c and the mixture 18:2w6,9c/18:0ante predominated during the development of Pisolithus sp. basidiocarps and went through dramatic changes during the process (Figure 3a,b,c). The relative percentages and quantities on a fresh matter basis of $16: 0,16: 1 \mathrm{w} 5 \mathrm{c}$, and 18:1w9c increased along the differentiation of the peridioles (Figure 3a,c), indicating that these compounds are the main fatty acids stored by the fungus. In mature peridioles, fatty acid 18:1w9c becomes the most important compound. The high quantity of $18: 1 \mathrm{w} 9 \mathrm{c}$ in the basidiospores indicates that this compound is the main fatty acid stored by Pisolithus sp. (Figure 3a,c).

The fatty acid concentration based on dry matter showed a different pattern, increasing as peridiole development progressed and achieving the highest level at the stage of mature peridioles (Figure 3b). Afterwards, concentrations decreased reaching the lowest values in the free basidiospores (Figure 3b). This behavior may be explained by the consumption of fatty acids for the synthesis of structural elements of the basidiocarp and basidiospores, with consequent decreases in the concentration of these compounds. In $A$. bisporus fruit bodies, the main fatty acid is the 
Table 1. Relative percentage (RP) and concentration of fatty acids of Pisolithus sp. basidiocarp sections characterized by the distinct developmental stages of peridioles

\begin{tabular}{|c|c|c|c|c|}
\hline Developmental stage & Fatty acids ${ }^{(1)}$ & $\mathbf{R P}$ & Dry matter & Fresh matter \\
\hline $\begin{array}{l}\text { I. Undifferentiated } \\
\text { peridioles } \\
\text { (Basal region of the } \\
\text { basidiocarp containing } \\
\text { undifferentiated } \\
\text { peridioles) }\end{array}$ & $\begin{array}{l}10: 0 \text { iso } \\
10: 0 \mathrm{OH} \\
11: 0 \text { ante } \\
12: 0 \\
12: 03 \mathrm{OH} \\
13: 0 \\
13: 0 \text { ante } \\
13: 02 \mathrm{OH} \\
14: 0 \\
15: 0 \\
15: 1 \text { iso F } \\
15: 1 \mathrm{I} / \mathrm{H} / 13: 03 \mathrm{OH} \\
15: 0 \text { ante } \\
16: 0 \\
16: 1 \mathrm{w} 5 \mathrm{c} \\
16: 1 \mathrm{w} 7 \mathrm{c} / 15 \text { iso } 2 \mathrm{OH} \\
17: 1 \mathrm{w} 8 \mathrm{c} \\
17: 1 \mathrm{w} 9 \mathrm{c} \\
18: 1 \mathrm{w} 9 \mathrm{c} \\
18: 2 \mathrm{w} 6,9 \mathrm{c} / 18: 0 \text { ante }\end{array}$ & $\begin{aligned} \% \\
<0.55 \\
<0.55 \\
<0.55 \\
<0.55 \\
<0.55 \\
<0.55 \\
<0.55 \\
<0.55 \\
<0.55 \\
5.17 \pm 0.53 \\
<0.55 \\
<0.55 \\
<0.55 \\
10.74 \pm 1.26 \\
5.21 \pm 0.16 \\
\quad 2.19 \pm 0.53 \\
2.15 \pm 1.87 \\
<0.55 \\
3 \pm 0.38 \\
\quad 66.26 \pm 5.52\end{aligned}$ & $\begin{aligned} & \\
&<6.00 \\
&<6.00 \\
&<6.00 \\
&<6.00 \\
&<6.00 \\
&<6.00 \\
&<6.00 \\
&<6.00 \\
&<6.00 \\
& 30.70 \pm 5.23 \\
&<6.00 \\
&<6.00 \\
&<6.00 \\
& 56.76 \pm 19.98 \\
& 31.07 \pm 5.69 \\
& 13.46 \pm 5.77 \\
& 12.94 \pm 11.43 \\
&<6.00 \\
& 18.15 \pm 5.61 \\
& 395.11 \pm 77.95\end{aligned}$ & $\begin{aligned} & \\
&< 1.70 \\
&< 1.70 \\
&< 1.70 \\
&< 1.70 \\
&< 1.70 \\
&< 1.70 \\
&< 1.70 \\
&< 1.70 \\
&< 1.70 \\
& 9.14 \pm 1.55 \\
&< 1.70 \\
&< 1.70 \\
&< 1.70 \\
& 16.9 \pm 5.95 \\
& 9.25 \pm 1.69 \\
& 4.01 \pm 1.72 \\
& 3.85 \pm 3.4 \\
&< 1.70 \\
& 5.41 \pm 1.67 \\
& 117.66 \pm 23.22\end{aligned}$ \\
\hline $\begin{array}{l}\text { II. Young peridioles } \\
\text { (N ewly differentiated } \\
\text { peridioles of small } \\
\text { size) }\end{array}$ & $\begin{array}{l}9: 03 \mathrm{OH} \\
12: 0 \text { ALDE } \\
15: 0 \\
16: 0 \\
16: 1 \mathrm{w} 5 \mathrm{c} \\
17: 1 \mathrm{w} 8 \mathrm{c} \\
18: 1 \mathrm{w} 9 \mathrm{c} \\
16: 1 \mathrm{w} 7 \mathrm{c} / 15 \text { iso } 2 \mathrm{OH} \\
17: 1 \text { iso/ante B } \\
18: 2 \mathrm{w} 6,9 \mathrm{c} / 18: 0 \text { ante }\end{array}$ & $\begin{array}{r}<0.55 \\
<0.55 \\
2.15 \pm 0.18 \\
14.57 \pm 0.16 \\
1.61 \pm 0.36 \\
2.05 \pm 0.22 \\
3.94 \pm 0.36 \\
2.84+0.71 \\
1.23 \pm 0.17 \\
71.25 \pm 1.00\end{array}$ & $\begin{array}{l}<6.00 \\
<6.00 \\
10.93 \pm 0.57 \\
65.93 \pm 4.39 \\
8.15 \pm 1.68 \\
10.37 \pm 0.51 \\
20.05 \pm 2.44 \\
14.28+2.63 \\
6.19 \pm 0.54 \\
362.48 \pm 26.85\end{array}$ & $\begin{array}{r}<1.70 \\
<1.70 \\
3.31 \pm 0.17 \\
19.95 \pm 1.33 \\
2.47 \pm 0.51 \\
31.4 \pm 0.15 \\
6.06 \pm 0.74 \\
4.32 \pm 0.79 \\
1.87 \pm 0.17 \\
109.65 \pm 8.12\end{array}$ \\
\hline $\begin{array}{l}\text { III. Mature peridioles } \\
\text { (Completely } \\
\text { differentiated } \\
\text { peridioles in hyphae } \\
\text { and basidia) }\end{array}$ & $\begin{array}{l}15: 0 \\
16: 0 \\
17: 1 \text { iso/ante } \mathrm{B} \\
16: 1 \mathrm{w} 5 \mathrm{c} \\
17: 1 \mathrm{w} 8 \mathrm{c} \\
18: 0 \\
18: 1 \mathrm{w} 9 \mathrm{c} \\
16: 1 \mathrm{w} 7 \mathrm{c} / 15 \text { iso } 2 \mathrm{OH} \\
18: 2 \mathrm{w} 6,9 \mathrm{c} / 18: 0 \text { ante }\end{array}$ & $\begin{array}{r}0.55 \pm 0.16 \\
17.6 \pm 0.17 \\
<0.55 \\
3.22 \pm 0.97 \\
0.84 \pm 0.18 \\
1.06 \pm 0.18 \\
40.7 \pm 6.14 \\
1.61 \pm 0.14 \\
34.1 \pm 6.14\end{array}$ & $\begin{aligned} 6.56 & \pm 1.23 \\
206.85 & \pm 23.35 \\
<6.00 & \\
40.06 & \pm 16.53 \\
10.09 & \pm 0.94 \\
13.10 & \pm 3.8 \\
502.11 & \pm 134.07 \\
19.59 & \pm 0.61 \\
412.4 & \pm 25.66\end{aligned}$ & $\begin{aligned} 2.14 & \pm 0.4 \\
67.54 & \pm 7.63 \\
<1.70 & \\
13.08 & \pm 5.4 \\
3.29 & \pm 0.31 \\
4.28 & \pm 1.24 \\
163.93 & \pm 43.77 \\
6.4 & \pm 0.2 \\
134.94 & \pm 8.38\end{aligned}$ \\
\hline $\begin{array}{l}\text { IV. Enclosed } \\
\text { basidiospores } \\
\text { (Mature spores } \\
\text { located in the upper } \\
\text { portion of a closed } \\
\text { basidiocarp) }\end{array}$ & $\begin{array}{l}16: 0 \\
18: 0 \\
16: 1 \mathrm{w} 5 \mathrm{c} \\
18: 1 \mathrm{w} 9 \mathrm{c} \\
16: 1 \mathrm{w} 7 \mathrm{c} / 15 \text { iso } 2 \mathrm{OH} \\
18: 2 \mathrm{w} 6,9 \mathrm{c} / 18: 0 \text { ante }\end{array}$ & $\begin{array}{r}20.44 \pm 0.36 \\
1.54 \pm 0.15 \\
11.19 \pm 0.35 \\
52.45 \pm 0.24 \\
1.13 \pm 0.03 \\
13.24 \pm 0.16\end{array}$ & $\begin{aligned} & 156.55 \pm 11.71 \\
& 12.24 \pm 2.08 \\
& 88.18 \pm 4.79 \\
& 414.01 \pm 33.08 \\
& 8.93 \pm 0.77 \\
& 104.46 \pm 8.9\end{aligned}$ & $\begin{array}{r}82.08 \pm 6.14 \\
6.42 \pm 1.09 \\
46.23 \pm 2.51 \\
217.07 \pm 17.34 \\
4.68 \pm 0.41 \\
54.77 \pm 4.66\end{array}$ \\
\hline $\begin{array}{l}\text { V. Free basidiospores } \\
\text { (Mature spores } \\
\text { collected from the } \\
\text { upper portion of a } \\
\text { ruptured basidiocarp) }\end{array}$ & $\begin{array}{l}14: 0 \\
16: 0 \\
18: 0 \\
16: 1 \mathrm{w} 5 \mathrm{c} \\
18: 1 \mathrm{w} 9 \mathrm{c} \\
16: 1 \mathrm{w} 7 \mathrm{c} / 15 \text { iso } 2 \mathrm{OH} \\
18: 2 \mathrm{w} 6,9 \mathrm{c} / 18: 0 \text { ante }\end{array}$ & $\begin{array}{r}<0.60 \\
20.77 \pm 0.02 \\
1.57 \pm 0.05 \\
12.17 \pm 0.09 \\
50.53 \pm 0.14 \\
1.29 \pm 0.01 \\
13.48 \pm 0.21\end{array}$ & $\begin{array}{r}<6.00 \\
87.8 \pm 5.07 \\
6.87 \pm 0.39 \\
53.05 \pm 2.76 \\
220.49 \pm 12.1 \\
5.65 \pm 0.32 \\
58.88 \pm 3.05\end{array}$ & $\begin{aligned}<1.70 & \\
76.37 & \pm 4.41 \\
5.97 & \pm 0.34 \\
46.15 & \pm 2.4 \\
191.81 & \pm 10.53 \\
4.91 & \pm 0.29 \\
51.14 & \pm 2.65\end{aligned}$ \\
\hline
\end{tabular}

(1) Fatty acids are designated by the total number of carbon atoms in the chain, followed by the number and position of insaturations. The "w" shows that the insaturation position is indicated from the methyl end of the fatty acid chain. The double bond configuration is indicated as cis (c) or trans (t). For example, 16:1w7c, is a 16-carbon fatty acid, with one insaturation at the seventh carbon from the methyl end of the molecule. The fatty acid ramification is designated as iso, one carbon from the methyl end, or anteiso, two carbon atoms from the methyl end. The hydroxyl group is indicated by $\mathrm{OH}$, numbered from the carboxyl terminal of the acid (ex. 16:0 3OH). (Adaptated from White et al., 1997). 

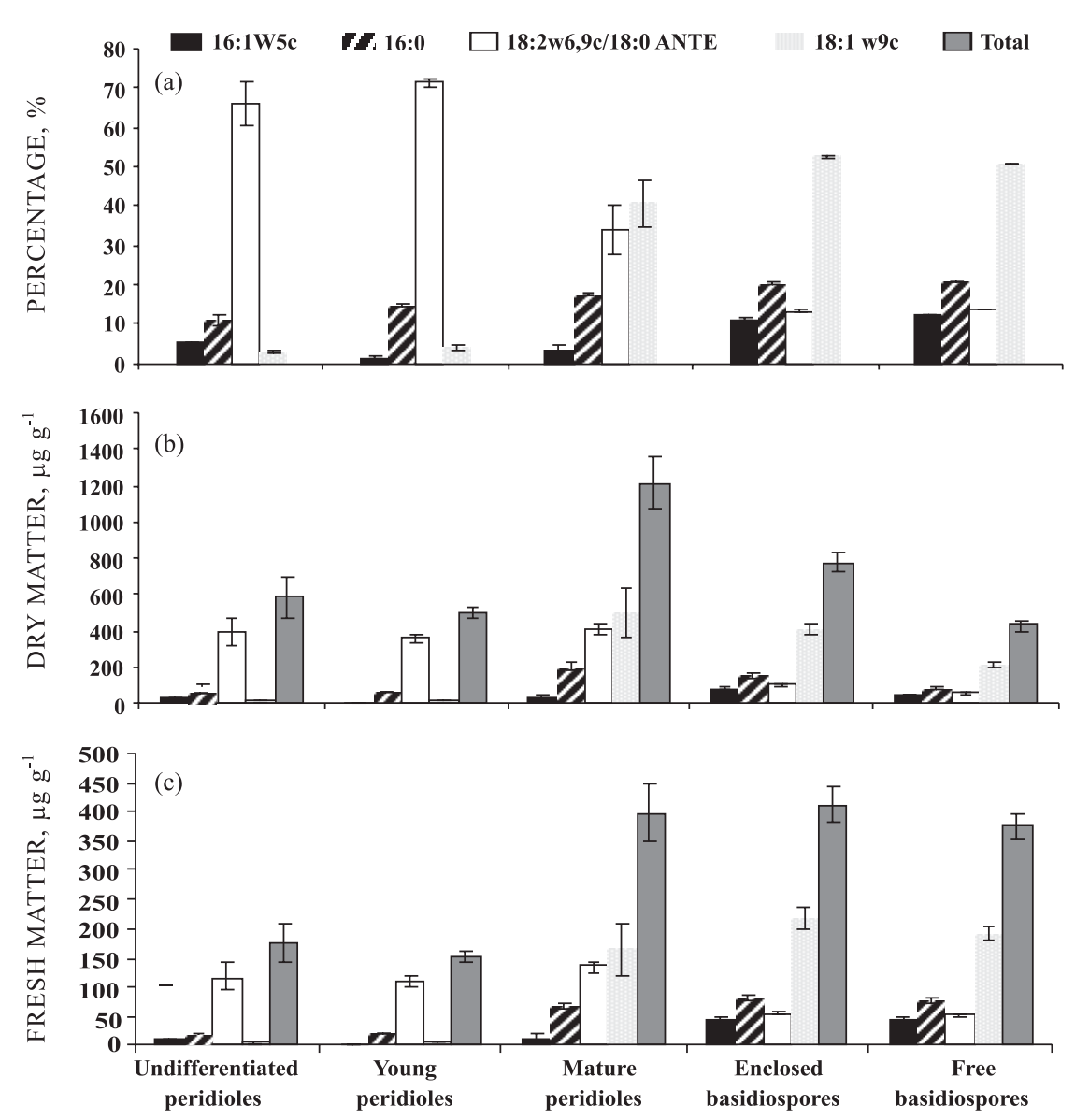

Figure 3. Relative percentage (a) and concentration of the main fatty acids based on dry and fresh matter during different developmental stages of the peridioles that constitute the basidiocarps of Pisolithus sp (b) and (c). Bars represent standard deviation.

18:2w9,12c, constituting the main storage material in this fungus (Feofilova et al., 2004).

The chemical composition of lipid reserves influences the process of spore germination, which requires large quantities of $\mathrm{C}$ and the mobilization of storage fatty acids (Morozova et al., 2002). Fatty acid analysis of Metharhizium anisopliae conidia revealed that amounts of linoleic acid in the most effective strains at biological pest control were higher than in the less effective (Pupin et al., 2000). The germination of $A$. nidulans spores is dependent not only on the types of fatty acids available as storage products, but also on carbohydrates present in the spores (Morozova et al., 2002). The low germination percentages reported so far for Pisolithus sp. (Costa, 2002; Pereira, 2004) and the role of lipid reserves in basidiospore germination is an important issue to be studied.

The results obtained for Pisolithus sp. corroborate previous results for some other fungal species according to which fatty acids with $18-\mathrm{C}$ chains and a single insaturation predominate as storage compounds in basidiomycetes, such as Amanita muscaria, Clitocybe sp., Ramaria sp., Agaricus sylvicola, Armillaria borealis, Cortinarius nemorensis, and
Russula delica (Dembitsky et al., 1992; Brondz et al., 2003). The amounts of fatty acids with more than one insaturation in these fungi are low. On the other hand, the fungi $A$. bisporus, $A$. campestris, Boletus edulis, Coprinus comatus, Pleurotus ostreatus, Oudemansiella radicata, and Armilaria mellea store fatty acids with 18-C chains and two insaturations as main compounds in the basidiospores (Feolifova et al., 2004; Yilmaz et al., 2006).

This is the first report on the qualitative and quantitative composition of fatty acids of Pisolithus sp. basidiocarps during basidiosporogenesis. Knowledge of the quantitative and qualitative composition of the $\mathrm{C}$ compounds stored in the basidiospores of Pisolithus sp. opens new perspectives for the study of the factors that affect basidiospore germination and $\mathrm{C}$ mobilization for the initial growth of germ tubes and hyphae.

The results obtained here suggest a role for fatty acids in the regulation of basidiocarp differentiation and basidiosporogenesis. Further research is being conducted to determine how important these compounds may be for the whole life cycle of Pisolithus sp. 


\section{CONCLUSIONS}

1. During basidiocarp development, a conspicuous distribution of lipids occurs in the hyphae, basidia, and basidiospores of Pisolithus sp. Fatty acid composition in the basidiocarps varies according to the developmental stage of the peridioles that constitute the fungal basidiocarp.

2. Oleic acid is the main storage fatty acid present in free basidiospores of Pisolithus sp.

3. Fatty acid accumulation in Pisolithus sp. basidiospores suggests sufficient provision of $\mathrm{C}$ and energy for spore germination. Further studies should be conducted to evaluate how lipid reserves are mobilized during spore germination to sustain the early stages of hyphal growth in the soil.

\section{LITERATURE CITED}

BAGO, B.; ZIPFEL, W.; WILLIAMS, R.M.; JUN, J.; ARREOLA, R.; LAMMERS, P.J.; PFEFFER, P.E. \& SHACHAR-HILL, Y. Translocation and utilization of fungal storage lipid in the arbuscular mycorrhizal symbiosis. Plant Physiol., 128:108-124, 2002

BALASUBRAMANIAN, S.; KIM, S. \& PODILA, G.K. Differential expression of a malate synthase gene during the preinfection stage of symbiosis in the ectomycorrhizal fungus Laccaria bicolor. New Phytol., 154:517-527, 2002.

BEHMER, O.A.; TOLOSA, E.M.C. \& FREITAS NETO, A.G. Manual de técnicas para histologia normal e patológica. São Paulo, EDART, Universidade de São Paulo, 1976. 43p.

BRONDZ, I.; HÆILAND, K. \& EKEBERG, D. Multivariate analysis of fatty acids in spores of higher basidiomycetes: A new method for chemotaxonomical classification of fungi. J. Chromatogr. B, 800:303-307, 2004.

BRUNDRETT, M.; BOUGHER, N.; DELL, B.; GROVE, T. \& MALAJCZUK, N. Working with mycorrhizas in forestry and agriculture. Canberra, Pirie Printers, 1996. 374p. (ACIAR Monograph, 32)

CHAMBERS, S.M. \& CAIRNEY, J.W.G. Pisolithus. In: CAIRNEY, J.W.G. \& CHAMBERS, S.M., eds. Ectomycorrhizal fungi: Key genera in profile. Berlin, Springer-Verlag, 1999. p.1-31.

COSTA, M.D. Germinação de esporos e formação de ectomicorrizas in vitro por estirpes monocarióticas de Pisolithus sp. Viçosa, MG, Universidade Federal de Viçosa, 2002. 153p. (Tese de Doutorado)

DEMBITSKY, V.M.; SHUBINA, E.E \& KASHIN, A.G. Phospholipid and fatty acid composition of some basidiomycetes. Phytochemistry, 31:845-849, 1992.
FEOFILOVA, E.P.; TERESHINA, V.M.; GARIBOVA, L.V.; ZAV'YALOVA, L.A.; MEMORSKAYA, A.S. \& MARYSHOVA, N.S. Germination of basidiospores of Agaricus bisporus. Appl. Biochem. Microbiol., 40: 220-226, 2004.

JEE, H. \& KO, W. Stimulation of sexual reproduction in Phytophthora cactorum and $P$. paratica by fatty acids and related compounds. Mycol. Res., 101:1140-1144, 1997.

KOPE, H.H. \& FORTIN, J.A. Germination and comparative morphology of basidiospores of Pisolithus arhizus. Mycologia, 82:350-357, 1990.

KAMISAKA, Y.; NODA, N.; SAKAI, T. \& KAWASAKI, K. Lipid bodies and lipid body formation in an oleaginous fungus, Mortierella ramanniana var. angulispora. Biochim. Biophys. Acta, 1438:185-198, 1999

LACZKO, E., BOLLER, T. \& WIEMKEN, V. Lipids in roots of Pinus sylvestris seedlings in mycelia of Pisolithus tinctorius during ectomycorrhiza formation: Changes in fatty acid and sterol composition. Plant Cell Environ., 27:27-40, 2003.

LAMMERS, P.J.; JUN, J.; ABUBAKER, J.; ARREOLA, R.; GOPALAN, A.,; BAGO, B.; HERNANDEZ-SEBASTIA, C.; ALLEN, J.W.; DOUDS, D.D. \& PFEFFER, P.E. The glyoxylate cycle in an arbuscular mycorrhizal fungus: Gene expression and carbon flow. Plant Physiol., 127:1287$1298,2001$.

MIMS, C.W. Ultrastructure of basidiospores of the mycorrhizal fungus Pisolithus tinctorius. Can. J. Bot., 58:1525-1533, 1980.

MOROZOVA, E.V.; KOZLOV, V.P.; TERESHINA, V.M.; MEMORSKAYA, A.S. \& FEOFILOVA, E.P. Changes in lipid and carbohydrate composition of Aspergillus niger conidia during germination. Appl. Biochem. Microbiol., 38:129-133, 2002

PEREIRA, G.M.D. Germinação "in vitro" de esporos de Pisolithus sp. Viçosa, MG, Universidade Federal de Viçosa, 2004. 65p. (Tese de Mestrado)

PFEFFER, P.E.; DOUDS Jr, D.D.; BÉCARD, G. \& SHACHARHILL, Y. Carbon uptake and the metabolism and transport of lipids in an arbuscular mycorrhiza. Plant Physiol., 120:587-598, 1999.

PUPIN, A.M.; MESSIAS, C.L.; PIEDRABUENA, A.E. \& ROBERTS, D.W. Total lipids and fatty acids of strains of Metharhizium anizopliae. Braz. J. Microbiol., 31:121-128, 2000 .

WANG, C.; XING, J.; CHIN, C. \& PETERS, J.S. Fatty acids with certain structural characteristics are potent inhibitors of germination and inducers of cell death of powdery mildew spores. Physiol. Molec. Plant Pathol., 61:151-161, 2002

WELLS, K. Ultrastructural features of developing and mature basidia and basidiospore of Schizophyllum commune. Mycologia, 57:236-261, 1965.

WHITE, D.C.; PINKART, H.C. \& RINGELBERG, D.B. IN: HURST, C.J.; KNUDSEN, G.R.; MCINERNEY, M.J.; STETZENBACH, L.D. \& WALTER, M.V., eds. Manual of environmental microbiology. Washington, D.C., ASM, 1997, 894p. 
YILMAZ, N.; SOLMAZ, M.; TÜRKEKUL, I. \& ELMATA, M. Fatty acid composition in some wild edible mushrooms growing in the middle Black Sea region of Turkey. Food Chem., 99:168-174, 2006.
YOON, K.S. \& MCLAUGHLIN, D.J. Basidiosporogenesis in Boletus rubinellus. II. Late spore development. Mycologia, 78:185-197, 1986. 